\title{
Julian Gruin
}

University of Amsterdam, Netherlands

\begin{abstract}
Digital credit scoring is driving a number of significant transformations in Chinese economy and society, catalyzing financial liberalization, deepening financial inclusion, and shifting economic power beyond the previously state-controlled commercial banking system. Yet the significance of financial technology is informed in turn by locally specific traditions of governance and regulation. This article critically interrogates the rise of Chinese fintech, reconceptualizing it as a process of financialization that is embedded in a Chinese systemsoriented authoritarian governance tradition. On the basis of documentary sources, Chineselanguage secondary literature, and fieldwork conducted from 2016-18, it argues that in addition to disrupting existing practices of financial intermediation, the emergence of novel digital credit scoring technologies is enabling new forms of algorithmic governance to be exercised over the process of financialization, which in turn represents an important component in the construction of China's neo-statist authoritarian capitalism. These findings have broader implications for how we understand the importance of new financial technologies in an era of big data, contributing to contemporary debates in international political economy, economic sociology, and Chinese studies.
\end{abstract}

\section{Keywords}

Authoritarian capitalism, China, digital credit scoring, technology, financialization, neo-statism

\section{Introduction}

China's financial system has experienced significant change since 2012. Although the large state-owned commercial banks remain its beating heart, the rapid growth of digital financial

\section{Corresponding author:}

Julian Gruin, Department of Political Science, University of Amsterdam, Postbus 15578, Amsterdam, Netherlands, 1001NB. Email: j.y.gruin@uva.nl. https://doi.org/10.2218/finsoc.v5i2.4135 
services (DFS) beyond this state-owned sector has had a transformative impact upon both the structure and the operations of the system, leading to China's emergence as the world's most important market for financial technology (fintech) both in absolute size and as a source of industry innovation (Claessens et al., 2018). Central political and broader social support for the growth of such financial innovation since the 2013 Third Plenum of the Chinese Communist Party (CCP) has been closely connected to the promise of 'tech national champions' leading a new wave of economic growth, led by middle-class consumption and greater efficiency in financial and other consumer services (Hu and Zheng, 2016). It is a market environment that offers enormous first mover advantages, embedded in an increasingly consumer-oriented society that is highly receptive to the 'disruption' of the statecontrolled banking system. China's fintech heavyweights, including Ant Financial, JD Finance, and Du Xiaoman, alongside a raft of no less ambitious smaller dedicated online lending firms, such as Dianrong, Lufax, and Yirendai, are extending competitive and market-driven digital financial services to individuals and enterprises that previously found access to financial capital difficult within the confines of a financially repressed traditional banking system.

The consequences of such transformations are not limited to the reform of China's financial system and economic growth model, but are of deep significance for the future of Chinese politics and society. Just as the growth of systemically significant technology firms in Western countries has given rise to contentious questions of their influence on democratic processes, the significance of China's new fintech firms extends to their potential impact on the CCP's 'authoritarian resilience' as it confronts challenges of deepening market-oriented reforms and the rise of the Chinese middle-class consumer. This impact takes two potential forms. First, such financial inclusion raises awareness and use of financial opportunities and processes, fostering an increasingly individualized investment-driven logic of entrepreneurialism and consumption (Hall, 2012; van der Zwan, 2014). Secondly, it is connected to the increasingly important role of public-private and state-business struggles over the control of information in a context of big data capitalism (Hansen and Porter, 2017; Richards and King, 2013). As such, the rise of online credit and investment services challenges the CCP's long-entrenched control over financial intermediation and allocation of capital at the meso-institutional level, as well as the deeper foundations of the social contract that has characterized Chinese citizens' trust in the CCP to provide opportunities for individual economic betterment and collective prosperity.

This article analyzes these tensions, examining the role of Chinese DFS in the evolving relationship between financial development and China's authoritarian capitalism. It argues that the rise of Chinese fintech represents more than a market-based utilization of new financial technologies in response to an entrenched state-dominated banking system, but rather constitutes an important institutional foundation in the ongoing construction of an authoritarian capitalist system. These foundations comprise an interlinked array of big data technologies, financial firms, and practices of digital credit scoring, cumulatively embedded in a unique authoritarian political culture. The political economy of Chinese fintech extends beyond the immediate dynamics of change within the financial system; it is a broader and more complex process of financialization involving also the transformation of social and economic governance structures.

I detail how the development of big data-driven credit scoring technologies for reducing financial transaction costs and increasing financial inclusion have assumed a broader significance in the context of new practices of 'algorithmic governance' (Campbell-Verduyn, Goguen, and Porter, 2017), through which big data algorithms' functions as market devices are both supplemented by and transmuted into tools of political power. This algorithmic 
governance exhibits the Chinese political economy's distinctive traits of deepening marketization combined with strongly authoritarian state capacity - the manifestation of China's 'networked authoritarianism' in the financial realm (MacKinnon, 2011). The analysis therefore develops a critique of the intertwined 'financial liberalization' and 'financial inclusion' discourses of Chinese fintech that portray this process as a largely progressive socio-economic development and a demonstration of the economic potentials made possible by technological change (Xie, Zou, and Liu, 2016b). Such a conclusion overlooks how specific technologies are always deeply embedded in social and political dynamics that transmute their function and operation; in this case, embedded in what Creemers (2017a: 85) describes as the CCP's broader project of placing "technology at the centre of an ambitious agenda for comprehensive reform of social and economic governance".

These arguments contribute to two important contemporary debates in the political economy of finance. First, the findings open up new conceptual avenues in the political economy of financial reform and financialization in authoritarian states such as China. Existing scholarship on the influence of financialization on democratic politics remains largely centered upon Anglo-American financial systems (Aitken, 2007; Bruff, 2014; Langley, 2007). I show how technological innovation - even when it reflects a form of 'market-oriented transition' - is connected to the practice of digital 'authoritarian resilience' and represents a continuation of, rather a rupture with, long-standing principles and structures of Chinese governance. In so doing I broaden the financialization debate beyond the world of Anglo-American financial capitalism and develop new opportunities for comparative analysis of the political consequences of financialization. Secondly, the article contributes to the deepening rapprochement between economic sociology and political economy in recognizing the need to contextualize the dynamics of market devices and technologies within the broader power relations of capitalist growth and development (Christophers, 2014). The embeddedness of these financial technologies within the Chinese political culture represents one set of conditions in which such technologies can give rise to unintended political consequences through a re-engineering of their usage and a transmutation of their economic and political potentials.

The remainder of the article proceeds as follows. In the next section I outline the analytical value of adopting the concept of financialization for understanding the nature and consequences of big data-driven financial technologies in China. The argument then proceeds in two empirical steps. First, I trace how the rise of Chinese fintech is generating new sources of financial value through a process of 'inclusive financial liberalization' in response to a financially repressed state-dominated system. I then turn to the deeper political dimensions of this process, examining how the rise of Chinese fintech is connected to the evolution of algorithmic governance in China. This involves both the need for the CCP to exert control over the financialization process, as well as its ambition to develop new forms of control through financialization. The analysis draws upon a range of primary sources including government policy documents, industry data, and 29 field interviews conducted in Beijing between October 2016 and September 2018. These interviews were obtained via a snowballing method to locate interviewees who could provide a perspective on the development of Chinese fintech from that of public governance (government officials), private enterprise (practitioners from the fintech industry) or policy research (think tank researchers). These are supported by recourse to the Chinese-language secondary literature. The concluding section discusses the implications of the analysis and explores avenues for further research. 


\section{Technology and financialization in authoritarian capitalism}

Since the goal of constructing the 'socialist market economy' was first declared in 1993, a state-controlled banking sector has lain at the core of the CCP's experimental approach to reform and opening, involving efforts to harness the economic efficiencies of domestic market competition, whilst guarding against its potentially destabilizing effects. One implicit assumption underlying much political economy analysis of China's financial 'liberalization' has therefore been that it transfers power over financial capital to actors - both individual and corporate - beyond the party-state and thus forms one aspect of a broader market-oriented developmental trajectory threatening the stability of CCP rule (see Ang, 2018; Yang, 2006; Yang, 2017). As history and the work of a number of other scholars has shown (Dickson, 2008; Gruin, 2016; Tsai, 2007), the CCP has exhibited remarkable capacity to manage the challenges raised by a rapidly evolving market economy.

The rise of fintech represents one more of these challenges (Wang, 2017). Despite the purported politico-economic advantages of increasing financial efficiency and broadening the financial base, the rise of deep, broad, and integrated 'fintech ecosystems' also represents a socio-economic challenge to the long-standing and politically important methods of control exercised by the CCP over financial markets and activities (Gruin, 2016). Fintech thus raises anew long-standing questions concerning the CCP's capacity to have its cake and eat it too, by both harnessing and constraining financial capital as an economic resource, and now increasingly also digital financialization as a deeper and broader socio-political project. The emergence of Chinese DFS therefore presents us with a new iteration of a familiar yet counterintuitive situation: that one of the primary sources of legitimacy-enhancing growth constitutes simultaneously a potential threat to CCP authority.

Much of the existing scholarly literature on the emergence of Chinese DFS concentrates on its related roles in accelerating financial liberalization and of financial inclusion as part of China's evolving developmental model (Chen, 2016; Huang, Lei, and Shen, 2016; Kshetri, 2016). This focus has its roots in the political economy of financial reform and efforts to parse the role of DFS in the growth of Chinese shadow banking, financial efficiency, and stability (Huang, Shen, Wang, and Guo, 2016; Li and Yi Tin, 2016; Tsai, 2015; 2016). This set of debates stands apart from those of political scientists and China scholars who emphasize the role of digital information and governance in the context of China's networked authoritarianism (MacKinnon, 2011; Tsai, 2017). This increasingly entails the construction of a technologydriven mode of 'social management' (Creemers, 2017a; Hoffman, 2017), a process also highlighted in the popular media, which tends to portray it - somewhat unfairly - as a direct manifestation of an Orwellian dystopia (e.g. Botsman, 2017). Nevertheless, such literature does not locate these dynamics in the broader political economy of Chinese capitalism, in which financial development and liberalization have potentially significant implications for the viability and consequences of Chinese authoritarian governance.

\section{Digital financial inclusion as financialization}

This article bridges these debates by reframing the emergence of DFS and digital credit scoring as a case of financialization. Such an approach opens up valuable heuristic opportunities for investigating the specific consequences of technological change in global finance. Although financialization is a contested and multi-faceted conceptual umbrella for a variety of phenomena (Christophers, 2015), its core premise remains the increasing importance of financial markets, motives, institutions, and elites in the operation of the 
economy and its governing institutions (Epstein, 2005). Reviews of financialization scholarship have identified three broad analytical levels to the concept: the macro-political economic, the meso-institutional, and the micro-cultural (van der Zwan, 2014). Interested in the distributive patterns of politico-economic power produced by financialization, economists and political scientists have tended to emphasize the macro and meso-analytical levels, focusing on the changing patterns of interaction between financial and non-financial sectors and firms, and the shifting relationships between political and financial institutions. By contrast, the microcultural delves deeper into how financialization "reshapes the way people think about their lives and the world around them" (Davis and Kim, 2015: 212). Financial participation underwrites discourses and ideologies of individual responsibility, risk-taking, and calculative practices of personal management (Aitken, 2007; Martin, 2002). These and other financial subjectivities can become not just supplemental to but constitutive of entire social systems, aggregating into what Mehrling (2017) labels 'financial society'.

The socio-political logics and imperatives of 'financial society' are most acutely pronounced in Anglo-American societies, whilst they are now increasingly evident in regions whose financial development has unfolded alongside the emergence and diffusion of global neoliberalism (Gonzalez, 2015). China has long-attempted to resist the strictures of globalized finance, even as it sought to attract and enlist foreign capital in its modernization drive. Its insulation from the direct consequences of the financial crises of the 1990s and 2000s morphed into a more sophisticated set of strategies to both embrace and constrain the power of global financial integration (McNally and Gruin, 2017). Whilst this strategy has proven relatively successful in reaping the rewards of integration whilst guarding against attendant macroeconomic risks, the influence of deeper, socio-culturally rooted dimensions of financial development represents a different form of financial globalization. Although closely tied to the evolution of neoliberalism as a transnational project, financialization should not be considered commensurate with its underlying logics and ideologies (Davis and Walsh, 2017).

One implication of adopting such a perspective towards the micro-foundations of financialization is that trajectories of financialization will vary significantly by socio-cultural context. Although the geographic horizons of the financialization literature have broadened significantly since their initial focus upon the Anglo-American heartland of financial capitalism, explicitly comparative studies of Chinese financialization have remained aloof of the microlevel and societal changes potentially wrought, by the same token largely assuming the universality of its drivers and causes (e.g. Karwowski and Stockhammer, 2017). Meanwhile, single-case studies of Chinese financialization have made significant progress in tracing the patterns of financialization at multiple analytical levels. From a macroeconomic perspective, they have revealed the influence of financialization on economic growth and structure (Jia and Winseck, 2018; Wang, 2015), corporate governance (Modell and Yang, 2018), and financial stability (Xia and Fuchs, 2016). Wang (2018) has examined how China's digital financial inclusion diverges from traditional developmental models of financial inclusion, instead incorporating both discourses and practices of financial inclusion into an increasingly financialized state-led capitalist model.

At the micro-cultural level, Chong (2018) has explored the everyday practices and narratives through which Chinese enterprises are becoming financialized, emphasizing contact with global professional service firms and 'best practices' in human resource management, corporate governance, and business ethics. Nevertheless, although such studies help us move beyond an understanding of financialization as simply a new logic of capital accumulation, they tend not to focus on the analytical linkages between the different levels at which financialization can be perceived. In one exception, Dal Maso (2015: 47) has characterized the 
growth of stock market participation since the early 1990s as a form of state-led "mass financialization". She links it to both an opening up of socio-economic space for individuals affected by the downsizing of the state-owned economy and associated welfare systems, as well as a role in the rhetoric of the Chinese regime's drive to buttress ideological support for the new socialist market economy.

This article's theoretical arguments are situated across these levels of analysis, seeking to connect the evolving macro-power relations of financialized capitalism with the microcultural mechanisms of how individual social relations are enrolled in its behavioural logics and practices. From this perspective, financialization at all levels is a deeply social process. Both its causes and consequences are socially rooted, with macroeconomic and institutional definitions of financialization serving as important and clear proxies for underlying realignments of socio-political norms and cultural discourses. By the same token, microcultural mechanisms underpinning financialization generate agency for influencing macropower relations; those able to modulate and redirect these logics are better equipped to simultaneously constrain and harness the power of financial capitalism. A corollary to these arguments is that the role of technology in financialization is mediated by a range of social and cultural factors. Innovation in information and communications technology serves to facilitate broader financial inclusion by rendering online financial services cheaper, more readily tailored to individual needs, and more widely available both temporally and geographically. Yet when coupled with the algorithms underpinning big data technologies, social media and messaging platforms also bring less sanguine consequences, serving as powerful mechanisms for diffusing and reifying certain financial logics and practices at the expense of others.

A sensitivity to the socio-political embeddedness of technological change and innovation is of importance to ongoing debates surrounding digital financial innovation in China and beyond for several reasons. First, by embedding the analysis of market devices more deeply in the socio-politics of finance capitalism, financialization becomes a more useful conceptual tool in the deepening conversation between economic sociology and political economy. The increasingly significant role played by financial technologies in catalyzing, accelerating, and modulating financialization processes raises broad issues of distribution, power, and regulation that have too rarely been elucidated by 'social studies of finance' scholars, who have focused more closely on the socio-technical market devices underpinning financial networks and exchanges (Coombs, 2016; Erturk, Froud, Johal, Leaver, and Williams, 2013). Technological devices that calculate and model economic activities are crucial objects of study for questions surrounding how markets are made possible (Muniesa, Millo, and Callon, 2007). Yet framing algorithms as economic assemblages that 'perform' markets in their image risks foregrounding their abstract and disembedded qualities, and downplaying the interests of political agents who both establish the structural parameters of this performativity and wield devices as specific political tools and weapons. Understanding the broader significance of fintech accordingly demands a nuanced analysis sensitive to the reciprocal influence between technological innovations and (different forms of) capitalist political economy. Cast in such light, financialization therefore goes beyond seeing the algorithms of big data-driven credit scoring as a disruptive technology affecting market evolution in a linear or homogenous fashion. Instead I show how algorithmic devices responsible for digital financial inclusion have both been shaped by - and deployed within - the authoritarian capitalism under construction by the CCP.

Secondly, the comparative capitalisms literature has long struggled to adequately deal with China's socialist market economy (Tsai, 2013). Conceptualizing the rise of Chinese DFS 
as a process of socio-politically embedded financialization brings debates on institutional change in Chinese finance into more fruitful conversation with the political economy of AngloAmerican financial systems that have hitherto dominated both the spread of financialized practices and discourses, as well as scholarly efforts to study them in comparative context. In this sense, rather than asking how fintech would affect Chinese politics and society, the question is one of how the significance of fintech is affected by its emergence through a highly complex and historically formed political tradition.

\section{Systemic stability in the Chinese political tradition}

The Chinese political tradition in which fintech is developing is characterized by its emphasis upon a systemic stability underpinned by a holistic integration or harmony of its constituent parts. For much of the twentieth century, Chinese society underwent the cyclical yet systematic destruction of social trust, reaching a climax during the Cultural Revolution, when trust between individuals and within communities was replaced by blind and exclusive faith in the ideological fervour of Mao Zedong. In line with its post-Mao transition from a 'revolutionary' to a 'governing party' (Heath, 2016), the overarching objective of contemporary Chinese governance remains the preservation and enhancement of the political authority of the CCP alongside the growth and development of Chinese economy and society. Since 1978, the CCP has endeavoured to preserve residual trust in its guarantee of social and economic progress in an era of profound social and institutional transformation (Gruin, 2019). This has proven increasingly difficult as the complexity and connectedness of the market economy and society has increased, giving rise to trust deficits across a range of social and economic sectors such as consumer protection, environmental regulation, corruption, and fraud (Ohlberg, Ahmed, and Lang, 2017), and the government's recognition that upgraded governance systems - both in ideological and technical terms - are integral for the CCP's continued capacity to govern.

The CCP's ambition of constructing an authoritarian capitalist society that reconciles the potentials afforded by a capitalist market economy with the strictures of an authoritarian political regime is increasingly apparent (Ang, 2018; Lieber, 2013). As Hoffman (2017) has argued, central to this governance model is a form of complex systems-thinking traceable to the 1970s, which views technology as a mechanism for achieving Leninist social management. In this systems-based conceptualization of governance, the constituent elements are evaluated with reference to their utility or function in achieving system-objectives: social harmony and economic development (Creemers, 2018). This blurs divisions between public and private, and the laying of responsibility for overall social development upon the citizenry, party members, commercial enterprises, social organizations, and government officials alike (Thornton, 2007). The outcome is a form of 'cyber-Leninism' (Creemers, 2017b) that has in turn undergone substantial upgrading since the start of the Xi administration, a turning point in the CCP's approach to utilizing and exploiting technology to restructure the Party's governing framework.

These distinctive political traits have influenced the development of digital credit scoring as an institutional foundation for an evolving authoritarian capitalist society, in which China's neo-statist logic of retaining macro-control over financial market evolution can be contrasted with the neoliberal tendency to vest epistemic authority in firms and corporate actors. The following sections accordingly trace the rise of Chinese fintech as an interlinked set of technologies, big data-based financial institutions, and practices like digital credit scoring, whose significance derives from their embeddedness in this distinctive political economy and 
the political tradition that underpins it. Contextualizing such technologies in the broader patterns of political and social governance illustrates their importance beyond the economic dimensions of financial inclusion and liberalization. Yet it also cautions against breathless accounts of the role of fintech in the Orwellian rise of China's surveillance state, for the significance of digital credit scoring lies not only in the imposition of explicit surveillance mechanisms. Rather, big data-driven financialization enables explicit incentives and implicit sanctions to be woven more deeply into the fabric of everyday life as part-and-parcel of the financialization of Chinese economy and society.

\section{Inclusive financial liberalization? The rise of Chinese fintech}

From its inception, Chinese DFS has generated broad expectations that it would play a significant and positive role within China's 'new economy' by furthering financial inclusion and accelerating deeper structural economic rebalancing. The capacity of big data-driven credit scoring, lending, and payments systems to facilitate this socio-economic transition constitutes one major dimension of its politico-economic significance, and provides an insight into the rationale underpinning central government support for the sector's growth and development. The emergence of Chinese fintech is therefore at its core a story of the politico-economic consequences of long-standing financial repression (Gruin, 2013; Tsai, 2015), leading to financing and efficiency gaps on both the lending and borrowing sides to small and medium enterprises (SMEs) and low-income households (Feyzioğlu, 2009; Hsiao, Shen, and Bian, 2015). Under the loose governance of the People's Bank of China (PBOC), the shadow banking system that emerged in the wake of the 2008 financial crisis was engaged in a balancing act between supporting economic growth through the existing investment-heavy developmental model and accelerating financial liberalization and competition within the banking sector (Hsu, Li, and Xue, 2014; Shen, 2016; Tsai, 2015).

Within this environment the growth of China's DFS sector since 2013 has been both rapid and sizable. Financial innovation linked to e-commerce has utilized new technology infrastructure and big data analytics to grant dramatically improved and faster access to financial services for consumers and SMEs (Xiang, Zhang, Wang, and Huang, 2017). After several years of explosive expansion, including the rise and fall of a large P2P online lending bubble, Chinese fintech is now entering a process of consolidation and maturation, with the new 'tech national champions' spearheading growth. Ant Financial, China's largest fintech firm, alone raised USD 14 billion in 2018, compared with a North American total of USD 12.1 billion and European of USD 3.8 billion (CB Insights, 2019). The firm has granted loans to more than 4 million businesses and individuals with a total amount of RMB 700 billion in direct lending (Cheng, 2017). Although online lending remains equivalent to less than $5 \%$ of domestic bank loans (01Caijing, 2018), this drastically understates the extent to which Chinese citizens' financial lives are moving online, and the rapid proliferation and uptake of retail lending and investment services.

The rise of DFS connects closely to questions surrounding the role of the financial system in China's broader economic development. The promotion of fintech as a viable avenue for market-oriented financial growth is closely tied to a broader array of efforts to address China's current macroeconomic conditions, contributing to three related economic policy goals: deepening China's financial reforms, improving the market environment, and transforming the overall national development model (Xiang et al., 2017; Xie, Zou, and Liu, 2014). This is echoed in much of the Western literature, which perceives the rise of fintech as heralding the long-awaited large-scale liberalization of China's financial sector (Huang et al., 2016; Ma, 
2017). Premier Li Keqiang encapsulated the sentiment when stating, at the opening of Tencent's WeBank, that the growth of online banks "will lower costs for and deliver practical benefits to small clients, while forcing traditional financial institutions to accelerate reforms" (PwC, 2015: 38, quoted in Loubere, 2017: 12).

This financial liberalization narrative around the emergence of fintech dovetails with that of financial inclusion. The 18th Central Committee meeting in November 2013 established an 'inclusive financial system' as a key priority for financial reform, whilst in March 2014, Premier Li Keqiang began to draw explicit connections between digital finance and financial inclusion (Li, 2014). A major push in this strategy to develop new growth drivers whilst preserving financial stability came in the 2015 Internet Plus Plan, which sought to integrate the mobile Internet, cloud computing, big data, and the Internet of Things with modern manufacturing, to encourage the healthy development of e-commerce, industrial networks, and internet banking (State Council of the PRC, 2015b). This policy initiative places financial sector reform front and centre, aiming to enhance China's state capacities and market efficiencies in e-commerce by promoting the contribution of digital financial services. Following quick on the heels of the Internet Plus Plan, on 31 December 2015, the State Council elevated financial inclusion to the status of a key pillar of national development and financial reform, stressing the central role of big data analytics, cloud computing, and the integration of offline and online commerce in enabling fintech firms to broaden access to financial services (State Council of the PRC, 2016). An initial laissez-faire attitude toward the sector's growth was followed by concerted and coordinated set of regulatory measures by the PBOC and China Banking Regulatory Commission (PBOC, 2015b; CBRC. 2016), which aimed to ensure that online financing channels are structured to maximize capital flows to SMEs and individual entrepreneurs, rather than giving rise to regulatory arbitrage. This policy discourse of 'inclusive financial liberalization' - along with the belief that DFS and online lending genuinely address a financing gap for SMEs and foster greater financial inclusion as a whole - is reinforced by the rise of the Chinese consumer as both a key driver of China's economic growth model over the next decades, as well as the 'financial empowerment' of the individual in an increasingly materialistic society (Xie et al., 2014; Huang et al., 2016). From this perspective, the policy incentives for promoting online financial inclusion and innovation as a means of capitalizing upon the Chinese consumer class as an economic force are clear (Li and Yi Tin, 2016).

Such economic rationales for fintech development are supplemented by visions of a more far-reaching transformation of Chinese socio-economic life, always with a positive spin. As Ant Financial's Chief Strategy Officer and respected academic economist Chen Long (2016: 231) describes it, "from Fintech to Finlife". In this process, "real life demand is the mother of innovation ... the reason why China's fintech developed so fast is that its development is tightly knitted to and supports consumption growth. As a result, technology, finance, and real-life need form a virtuous circle". Widespread societal support for fintech is closely connected to enthusiasm for a future imaginary of liberalized financial markets and access to financial services for individuals and entrepreneurs unencumbered by the strictures of state authority (Bai, 2016; Wang, 2017). This underscores the receptivity of this rapidly burgeoning consumer class to the reshaping of lifestyles and consumption patterns around the growth of ecommerce, fintech, and the big data-driven business practices that underpin them. It further embeds the rise of fintech within a socially legitimated political discourse of economic development and modernization.

As the sector began to gradually mature, the broader institutional foundation of Chinese DFS began to take clearer shape. The core source of financial value in Chinese online lending is the collection of information on consumer and business economic behaviour, predominantly 
oriented thus far around e-commerce (Tang, Zhang, and He, 2014). Yet an early challenge lay in developing usable credit scores, given the underdeveloped state of Chinese consumer finance and the historical exclusion of SMEs from formal credit channels (CFI, 2016). In early 2015, eight private technology firms were granted permission through a PBOC pilot program to commence 'preparatory work' on establishing formal credit databases and scoring methodologies. Although such pilot programs (for example, Ant Financial's Zhima [aka Sesame] Credit) have been conflated with broader systems of surveillance (see Botsman, 2017), there are nevertheless substantive links between the PBOC's pilot program, and the broader work of constructing a social credit system. Through Alibaba's extensive reach into all aspects of consumer's online behaviour, Ant Financial has access to data on online purchases, utility bill payments, social network use, mobile phone records, and previous micro-finance history, and is constructing the world's most comprehensive online financial services platform (Caixin 2017), whilst other tech giants Baidu, Tencent, and Jingdong are developing equally comprehensive credit scoring databases (Caixin, 2017; Millward, 2016).

Online lending and the emergence of digital credit scoring is facilitating shifts in China's model of growth and development, enabling the expansion of new digital economies and markets, whilst also accelerating a rupture with the financial repression that has longcharacterized the role of finance and particularly the banking system in China's economic reform and development. MYbank, Ant Financial's online-only private bank, provides a '310' loan service (three-minute application, one-second approval and grant, and zero manual intervention) that is specifically geared towards micro and small entrepreneurs that have grown up within the Alibaba e-commerce ecosystem (Cheng, 2017). The use of big data analytics in credit risk assessment has led to JD Finance having served over 100,000 SMEs with supply chain finance solutions amounting to a total of RMB 250 billion, concentrating not on a traditional loan model but instead using big data analytics to offer loan packages with characteristics tailored to individual enterprises such as flexible amortization rates (Dong, 2017). As a means of capitalizing upon the Chinese consumer class as an economic force central to China's broader structural economic rebalancing (Barton, Chen, and Jin, 2013), the economic incentives for promoting online financial inclusion and innovation then are clear to Chinese policymakers and are increasingly forming the basis for economic development plans (Interview, 13 September 2017; Li and Yi Tin 2016, 175).

DFS-driven 'inclusive financial liberalization' functions thus as a catalyst of financialization. As Gabor and Brooks (2016) have observed, the developmental potentials afforded by fintech often obscure the ways in which it functions as an instrument of financialization. Through a process of 'constituting the unbanked' (Aitken, 2017), financial inclusion - and digital financial inclusion doubly so - involves making visible and extracting value from previously excluded potential consumers or investors. In the Chinese case, this process has implications for the locus and exercise of political power, as the capture by large private financial firms not just of this economic value, but also of influence over consumer financing behaviors, potentially challenges the longstanding control exercised by the state over financial capital. Yet it also bolsters potentials for algorithmic governance by integrating political priorities and strictures into the evolving fabric of financial networks and dependencies.

\section{Fintech and the rise of algorithmic governance in China}

The rise of DFS as a foundation for inclusive financial liberalization thus marks a subtle but significant shift in the socio-economic reach of the Chinese financial system, as well as the 
underlying logics of newly formed financial networks and relationships. Accelerating China's financial inclusion in this way begins to shift the locus of financial authority from the traditional network of commercial banks to those overseeing and exploiting the infrastructure of digital finance itself: the databases and data-processing techniques at the heart of algorithmic credit scoring. As Mader (2016: 78) observed with reference to the implications of the broader financial inclusion movement, "digital financial inclusion, if fulfilled, would immensely empower whoever controls the new monetary infrastructures." Multiple sets of power relations are affected and potentially reconfigured through digital financialization, as big data comes increasingly to serve both as a tool and lever of algorithmic governance (Campbell-Verduyn, Goguen, and Porter, 2016). DFS-led financialization thus presents novel challenges for the CCP. Digital financial inclusion involves a potentially rapid diffusion of personal economic and behavioural data; data that is useful not just for making financial decisions, but which can also be used to influence wider social attitudes and incentives.

The holistic systems-thinking at the core of contemporary Chinese social governance is reflected in the history of the CCP using the financial system as both an economic and a sociopolitical tool, particularly since reform and opening commenced in 1978 (Heilmann, 2008; Gruin, 2019). One consequence is that economic growth is not pursued with firm ideological distinctions between market-led economic innovation and state-guided economic upgrading, since either mode of change must remain within the purview and control of the party (Heilmann, 2005; McNally, 2012; Gruin, 2016). The close industry-government coordination in the development of credit databases and data-processing techniques fits squarely within this tradition, blurring the lines between public and private in harnessing the financial system as a political as well as economic tool. Accordingly, as the next two sub-sections detail, the greater politico-economic significance of Chinese DFS arises from its role not just as a means of making visible and extracting economic value from the financially repressed Chinese consumer, but in laying the technological foundations for a more wide-ranging mode of social management and governance

\section{Constraining digital financialization: Consolidation and control}

One of the key objectives of the 2015 Guiding Proposal was to achieve industry consolidation within the rapidly burgeoning online lending industry, and both broaden and deepen the financial services offered by large companies (Interview, 23 September 2016). This consolidation also took on greater political significance, as the large tech firms could be regulated in a more balanced manner, and were both amenable to and dependent on close coordination with the government in order to preserve their political support and market position (Feng 2017; Interview, 4 October 2016). Whilst regulatory arbitrage beyond the banks in a financially repressed and conservative regulatory environment had been one of the initial catalysts for the emergence of digital finance, industry consolidation was now seen as both reducing financial risk and increasing monitoring capacity (Interview, 27 September 2016; Interview, 3 October 2016).

Industry-government coordination in digital credit scoring took more explicit form in March 2016, when the National Internet Finance Association (NIFA) was established in Shanghai, with CreditEase as Executive Director, and Li Dongrong, former PBOC Deputy Governor, as serving President. Firmly under the administrative purview of the PBOC, the NIFA represents one element of the government's efforts to exercise control over the evolution of the country's digital credit scoring infrastructure. One of its early projects was to establish the new digital Credit Information Sharing Platform (CISP), launched in September 2016 in 
conjunction with the PBOC. With 17 NIFA members including Ant Financial, JD Finance, and Lufax present from its inception, this platform brought Chinese credit scoring genuinely into the algorithmic era (Yang, 2016). The platform offered promise of solving one of the biggest problems of online lending platforms operating in the absence of traditional in-depth credit assessment procedures. Information asymmetry and incompleteness, as well as data sharing across multiple platforms, have proven significant hurdles in the way of an accurate and reliable credit scoring mechanism. CISP operates by way of a generalized information dissemination system, so that customer and competitive information remain protected. The synergy between the interests of the sector and the government are apparent in Li Dongrong's statement at the new platform's launch:

The credit information recorded through the platform can not only improve the internet finance industry credit system, but also complement with the existing data in the national financial credit information database and other industry credit databases, further consolidating the social credit system's information foundation. (NIFA, 2016: n.p.)

The NIFA's pursuit of this objective through the CISP has been bolstered by wider national policy support. For example, Yiwu, one of China's leading trade hubs for manufactured goods, was identified by the PBOC and National Development and Reform Commission (NDRC) as one of twelve 'demonstration cities' for integrating social credit systems with finance, foreign trade, and market supervision (PBOC and NDRC, 2017; Xinhua, 2018a). The NIFA has paid special attention to the Yiwu plans, seeking ways to integrate the CISP with both national and local government efforts to compile usable credit databases, including the development of integrated cloud storage for financial information managed by a state-owned enterprise under the control of the CBRC (STCN, 2018).

These patterns of industry-government control, coordination, and cooperation are part of what Creemers (2018: 1 ) refers to as an "evolving practice of control". The largest lending platforms have been central to this push for regulation and the direction of its development. Key members of the NIFA have spoken of the close working relationship between regulators and industry players (CNTV, 2016). The essence of the compact reached between the new heavyweight DFS providers and the government is clear: from the industry's perspective, their willingness to confront existing banking monopolies grant them access to the front lines of the Chinese consumer revolution, as long as they fully meet central government expectations for the sharing, analysis, and utilization of underlying data (Interview, 4 October 2016; Interview, 15 September 2017). Just as with the establishment of its wider e-commerce empire, Ant Financial has been closely aligned with the priorities of regulators in the development of its financial business (Elliott and Qiao, 2015). Ant Financial is now prepared to open its systems and data to the central bank and other authorities' real-time monitoring and supervision (ECNS, 2015), and there remains little doubt that regulatory authorities are in control of the overall agenda (Interview, 29 September 2016; Interview, 4 October 2016).

The government in turn has a clear interest in exercising control over such firms as Ant Financial. As one source with knowledge of Ant's growing scrutiny from regulatory authorities tells it, "as a non-bank, non-state-owned institution in China, it's not allowed to independently grow too big to manage" (Zhang and Ruwitch, 2018: n.p.). Party committees are not merely in existence at the country's largest tech firms, but have been effective in monitoring their alignment with government priorities and policies (Interview, 14 September 2017). Eight major technology firms were initially granted pilot licenses to develop consumer credit scores, however, the PBOC opted later to merge the platforms into one unified credit scoring organization. Under NIFA's supervision, Baihang Credit Scoring is China's first unified private 
platform to provide personal credit information services, and is intended to supplement the existing state-run personal credit database (Xinhua, 2018b). Financial inclusion is not only about developing new domains from which to extract economic value, but also - and potentially more importantly - about ensuring that the potentials offered through digital credit scoring techniques remain under government control and management. As the next section details, the development of China's broader social credit system (SCS) provides an insight into these potentials, illustrating how big data-driven financialization can also be leveraged to enable novel forms of algorithmic governance to emerge and take shape.

\section{Leveraging digital financialization: Governance potentials of algorithmic credit scoring}

The preliminary plan for a comprehensive social credit system was announced in 2014 and forms the blueprint for a broader plan of upgrading both social and economic supervision through technological innovation (State Council of the PRC, 2014). New financial technologies are explicitly linked to this social engineering agenda, which seeks to create a 'more civilized' society via improvements in the natural, psychological, and social 'quality' (suzhi) of the citizenry (Loubere, 2017: 15). This objective has taken on particular significance in the context of the rise of the Chinese consumer, a process closely connected to questions of socio-political change in reform-era China and subject to careful 'ideology management' by the CCP (Goodman, 2014). The holistic systems-oriented focus of Chinese governance that blurs the boundaries between public and private also complicates liberal notions of public and private data. As Chen Gang (2016: 12) opened with in an influential article, "in the present era, data has become a fundamental national strategic resource". In accordance with the holistic systems-oriented focus of Chinese governance, constructing usable digital credit databases is an integrated process unfolding along two tracks within the private and state sectors. The construction by large e-commerce and tech platforms of large repositories of financially valuable consumer data is being complemented by coordinated efforts among financial regulatory bodies, such as the $\mathrm{PBOC}$, and other central government agencies including the NDRC and the State Internet Information Office, the latter of which is charged with control over China's internet censorship and propaganda regimes (see Table 1).

The core public repository of credit information is the Credit Reference Centre (CRC) of the People's Bank of China, which provides a high quality of existing historical credit data. The CRC system was initially established in 2004 and will constitute an important foundation for the broader SCS (PBOC, 2015a). Amongst other existing certified financial institutions, the Postal Savings Bank of China, with the largest branch network in the country, is supplying financial data on otherwise difficult-to-evaluate rural customers (CFI, 2016). Additionally, uncertified credit institutions provide lending information, alongside data from public sector entities handling credit transactions such as phone bills and property tax payments, information from law enforcement agencies, and from the court system. All of this is being further integrated into the National Credit Information Sharing Platform, which has been operational since October 2015, and currently includes almost 400 datasets by more than 30 central ministries and governmental agencies (NDRC, 2016). These two data collection and processing infrastructures - one borne directly out of consumers' online activities, the other founded upon public records and existing databases - are expected to merge together over the next years, even if the intention is not to produce one single 'credit score' as a result, but to enable data to be utilized for a variety of different purposes (Interview, 2 October 2016; Interview, 30 September 2016; Interview, 29 September 2016; Interview, 15 September 2017). This mutability between private sector initiatives to support commercial business and 
the government's objective to implement broader systems of social governance is a natural reflection of China's distinctive political tradition.

Table 1. Illustrative data sources for private and public financial credit scoring mechanisms. Source: Ant Financial, October 2016 (updated September 2017); PBOC.

\begin{tabular}{|c|c|c|c|}
\hline Credit system & & Ant Financial & People's Bank of China \\
\hline \multirow[t]{2}{*}{$\begin{array}{l}\text { Number of } \\
\text { businesses }\end{array}$} & $\begin{array}{l}\text { Corporate } \\
\text { credit }\end{array}$ & >8 million (TaoBao alone) & $>20$ million \\
\hline & $\begin{array}{l}\text { Individual } \\
\text { credit }\end{array}$ & >245 million (TaoBao alone) & >900 million \\
\hline \multirow[t]{2}{*}{$\begin{array}{l}\text { Nature of credit } \\
\text { information }\end{array}$} & $\begin{array}{l}\text { Corporate } \\
\text { credit }\end{array}$ & $\begin{array}{l}\text { All information relating to } \\
\text { business operation, } \\
\text { including identification, } \\
\text { volume, activity level, } \\
\text { inventory, rating, cash flow, } \\
\text { and utility bills, etc. }\end{array}$ & $\begin{array}{l}\text { Identification, credit } \\
\text { information, social security } \\
\text { payments and housing } \\
\text { acquisition fund, quality } \\
\text { control information, salary } \\
\text { arrears, utility payments }\end{array}$ \\
\hline & $\begin{array}{l}\text { Individual } \\
\text { credit }\end{array}$ & $\begin{array}{l}\text { Buyer's information and } \\
\text { corporate credit system, } \\
\text { buyers identification, online } \\
\text { expenditures histories, } \\
\text { social activity }\end{array}$ & $\begin{array}{l}\text { Personal credit information, } \\
\text { identification, social security, } \\
\text { payments, property dealings, } \\
\text { legal records }\end{array}$ \\
\hline Data source & & Automatic recording & $\begin{array}{l}\text { PBOC-regulated financial } \\
\text { institutions, some online } \\
\text { lenders, and government } \\
\text { agencies }\end{array}$ \\
\hline
\end{tabular}

The initial plan for the social credit system did not refer explicitly to the use of algorithmic big data analytics. Yet to assume that this means data collected purely for the purposes of financial risk management will never play a role in the broader matrix of social governance mechanisms would appear naïve. As one industry professional observed, the 2014 SCS plan extended through to 2020 , but "that is not the end of the process. There will obviously be a new plan after that." (Interview, 15 September 2017). In this light, it is less surprising then that the more recent 2017 State Council notice on the 13th Five-Year Plan for Market Supervision refers specifically to establishing and 'perfecting' new regulatory mechanisms involving "credit supervision, big data supervision, multidimensional collective governance" and so on (State Council of the PRC, 2017, n.p.). The same document also places the role of technology front and centre in undergirding this system of market supervision that expands the concept of 
credit ratings far beyond financial metrics, to include social, political, and environmental factors both in terms of data inputs and rating outputs (State Council of the PRC, 2017). Likewise, in the implementation of the Internet Plus Plan, the State Council has underscored the importance of big data analytic techniques to enhance 'social governance ability' at all levels of government, as well as the expectation of collaboration between government and tech firms in establishing the necessary credit information sharing platforms (State Council of the PRC, 2015a). Unsurprisingly, the substantive details of the algorithms that will produce these evaluations are as yet and will likely remain unknown. But the intent is clear: a constant monitoring presence of automatically generated and updated credit rating scores, which will in the terms of official discourse - constitute 'self-disciplining enforcement' mechanisms, at the level of both the individual citizen and the corporate entity (State Council of the PRC, 2017).

Both the empirical data sources as well as the algorithmic scoring techniques being developed across the range of DFS players are thus integral elements in transferring the practice and methodologies of financial credit rating to a broader range of quantifiable social and political benchmarks (Yan and Li, 2014, 291; Xie, Zou, and Liu, 2016b). Although there is little public acknowledgement of this process, the extent to which the laws and regulations defining the limits of data sharing between tech firms and the government reflect Beijing's political priorities is widely known amongst officials and industry alike (Interview, 13 September 2017). One influential former financial policymaker describes the goal in these terms:

Financial services will be available to all, and everyone will enjoy the benefits. In this way, Internet finance is more democratic than a finance controlled by professional elites ... Individuals (or institutions) have many stakeholders, who all have some information about their wealth, employment status, personality, and so on. If all stakeholders' information is released and pooled on social networks, and inaccurate information is disputed or filtered through social networks and search engines, we will get a reliable picture of their creditworthiness. Social networks also enable the accumulation of 'social capital' among people, with which costs of financial activities will drop considerably and opportunistic behaviors will be constrained. (Xie, Zou, and Liu, 2016a)

Such visions underscore just how fine a line there is between the use of credit scoring algorithms for evaluating financial creditworthiness on the one hand and socio-political trustworthiness on the other. Those technologies underpinning financial data collection and processing become increasingly mutable instruments of financial governance and social management, helping ensure that the financialization of Chinese society buttresses, rather than undermines, the existing power structures of CCP-led authoritarian capitalism

\section{Conclusion}

The core argument advanced in this article has been that the rise of Chinese DFS constitutes a digital financialization process embedding technological innovation within the distinctive political economy of Chinese authoritarian capitalism. Its impact arises from the interaction of four factors: the emergence of big data credit scoring technologies, an economic growth model demanding a more open and efficient financial system, a retail market environment primed for the uptake of digital financial services, and an authoritarian and ideologically robust state apparatus seeking to maximize new opportunities for socio-economic development whilst minimizing related threats to systemic stability and authoritarian control. Although its full contours are only beginning to emerge, digital financialization is generating new tools and 
opportunities for the CCP to monitor both individual and corporate actors, to sanction them if their behaviours are 'non-approved', and to slowly reshape social agency itself into an exercise in satisfying algorithmic templates of economic and social behavior.

Analyzing the rise of Chinese fintech in this way has wider implications for our understanding and study of how technological shifts at the heart of financial market practices and structures can reshape the politics of money and finance. Reframing big data-driven financial liberalization as a form of digital financialization embedded in the broader politics of capitalist development illustrates the effect of distinctive political traditions and economic structures on the nature and consequences of institutional change. The construction of China's digital credit scoring infrastructure is one manifestation of the myriad potential ways in which advances in financial technology open up new opportunities for socio-economic 'development' as well as the exercise of political authority.

This study's findings thus raise questions deserving further research into how financialization processes can be analyzed in comparative context. First, it calls for further theorization of different factors that influence financialization in different (trans)national contexts and the accompanying diffusion of technologies and practices. The developments analyzed here are just one historical instantiation of how technology can interact with a distinctive political tradition so as to present a novel governance strategy for addressing a long-standing politico-economic problem. In other contexts, different socio-cultural factors might be equally important, for example, the role of Islamic philosophy and ideology (see Rethel, 2011) as both a source of normative principles guiding the application of big data technologies to financial intermediation, as well as an array of institutionalized power structures shaping patterns of politico-economic power and authority.

Secondly, this issue of the nature of 'the digital' and the crucial role played by technology in contemporary financial inclusion and financialization speaks to deeper transformations in governance across liberal and illiberal societies alike, as big data technologies are increasingly deployed to monitor, predict, and actively generate the behaviours of technology users. Such practices of algorithmic governance are agnostic to the division between the public sphere of government and the private sphere of enterprise, calling into question the ongoing salience of conceptual dichotomies between 'democratic' and 'authoritarian' capitalism. This distinction becomes increasingly ambiguous when it comes to how the ownership, valorization, and exploitation of personal data can function as mechanisms of algorithmic governance. Chinese neo-statism and Anglo-American neoliberalism can each rely upon similar tools and technologies of socio-economic surveillance and biopolitics, despite the differing balance of power between juridical sovereign authority (neo-statism) and market-situated capital (neoliberalism). The Chinese case thus provides one instructive example of the role that big data and digital credit scoring can play in consolidating non-liberal forms of technologyenabled financial capitalism. At a time when calls are heard for the Western world's largest media technology firms to be regulated as utilities, we must be alert and alive to the potentials of fintech-led financialization to likewise consolidate and deepen the authoritarian cultural logics and institutional structures of neoliberal capitalism. 


\section{References}

01Caijing (2018) 2018 Report on the Development of China's Online Lending Service Industry

[Chinese language]. Beijing: 01Caijing.

Aitken, R. (2007) Performing Capital: Toward a Cultural Economy of Popular and Global Finance.

Basingstoke: Palgrave.

Aitken, R. (2017) 'All data is credit data': Constituting the unbanked. Competition \& Change, 21(4): 274-300.

Ang, Y.Y. (2018) Autocracy with Chinese characteristics. Foreign Affairs, May/June: 39-48.

Bai, C. (2016) The origin and role of inclusive finance in China. China Development Gateway. Available at: <http://en.chinagate.cn/2016-06/06/content_38610696.htm>. Accessed 21 September 2018.

Barton, D., Chen, Y. and Jin, A. (2013) Mapping China's middle class. McKinsey Quarterly, 3: 54-60.

Botsman, R. (2017) Big data meets big brother as China moves to rate its citizens. WIRED UK. Available at: <https://www.wired.co.uk/article/chinese-government-social-credit-score-privacy-invasion>. Accessed 27 October 2017.

Bruff, I. (2014) The rise of authoritarian neoliberalism. Rethinking Marxism, 26(1): 113-29.

Caixin (2016) Within P2P regulation 'dual responsibility' system the CBRC assumes responsibility for third party deposits [Chinese language]. Caixin, 24 August 2016.

Caixin (2017) Ant Financial's credit scoring ambitions crawl ahead with two new deals. Caixin Global, 10 May 2017.

Campbell-Verduyn, M., Goguen, M. and Porter, T. (2017) Big data and algorithmic governance: The case of financial practices. New Political Economy, 22(2): 219-36.

CB Insights (2019) 2019 Fintech Trends to Watch. New York: CB Insights.

CBRC (2006) Guidelines on Commercial Banks' Financial Innovation [Chinese language]. Beijing: China Banking Regulatory Commission.

CBRC (2016) Interim Law on the Management of Internet Lending Information Intermediaries [Chinese language]. Beijing: China Banking Regulatory Commission.

CFI (2016) How new credit scores might help bridge China's credit gap. Center for Financial Inclusion. Available at: <https://www.centerforfinancialinclusion.org/how-new-credit-scores-might-helpbridge-chinas-credit-gap $>$. Accessed 17 October 2018.

Chen, G. (2016) Use big data thinking and methods to enhance the government's governing capacity [Chinese language]. Qiushi, 12: 15-18.

Chen, L. (2016) From fintech to finlife: The case of fintech development in China. China Economic Journal, 9(3): 225-39.

Cheng, O. (2018) Inclusive Growth and E-Commerce: China's Experience. Hangzhou: AliResearch.

Chong, K. (2018) Best Practice: Management Consulting and the Ethics of Financialization in China.

Durham, NC: Duke University Press.

Christophers, B. (2014) From Marx to market and back again: Performing the economy. Geoforum, 57 (November): 12-20.

Christophers, B. (2015) The limits to financialization. Dialogues in Human Geography, 5(2): 183-200.

Claessens, S., Frost, J., Turner, G., and Feng, Z. (2018) Fintech credit markets around the world: Size, drivers and policy issues. BIS Quarterly Review, September: 29-49.

CNTV (2016) PBOC sets up advisory body. CNTV, 26 March. Available at: <http://english.cntv.cn/2016/03/26/VIDEKOJJSIzIFLaMsCd9gkQE160326.shtml>. Accessed 13 September 2016.

Coombs, N. (2016) What is an algorithm? Financial regulation in the era of high- frequency trading. Economy and Society, 45(2): 278-302. 
Creemers, R. (2017a) Cyber China: Upgrading propaganda, public opinion work and social management for the twenty-first century. Journal of Contemporary China, 26(103): 85-100.

Creemers, R. (2017b) Cyber-Leninism: The political culture of the Chinese internet. In: Price, M. and Stremlau, N. (eds.) Speech and Society in Turbulent Times. Cambridge: Cambridge University Press, 255-73.

Creemers, R. (2018) China's social credit system: An evolving practice of control. SSRN Papers, 3175792. Rochester: Social Science Research Network.

Dal Maso, G. (2015) The financialization rush: Responding to precarious labor and social security by investing in the Chinese stock market. South Atlantic Quarterly, 114(1): 47-64.

Davis, A. and Walsh, C. (2017) Distinguishing financialization from neoliberalism. Theory, Culture \& Society, 34(5-6): 27-51.

Davis, G.F. and Kim, S. (2015) Financialization of the economy. Annual Review of Sociology, 41(1): 20321.

Dickson, B. (2008) Wealth into Power: The Communist Party's Embrace of China's Private Sector. Cambridge: Cambridge University Press.

Dong, T. (2017) Quick take: JD.com finance unit launches microlending in Chongqing. Caixing Global, Available at: <https://www.caixinglobal.com/2017-10-19/101158477.html>. Accessed 20 October 2017.

ECNS (2015) China to issue guidelines for web finance companies. Available at: <http://www.ecns.cn/business/2015/03-05/156739.shtml>. Accessed 5 March 2018.

Elliott, D. and Yu, Q. (2015) Reforming Shadow Banking in China. Washington, DC: Brookings Institution.

Epstein, G.A. (2005) Financialization and the World Economy. Cheltenham: Edward Elgar.

Erturk, I., Froud, J., Johal, S., Leaver, A. and Williams, K. (2013) (How) do devices matter in finance? Journal of Cultural Economy, 6(3): 336-52.

Feng, E. (2017) Chinese tech groups display closer ties with Communist Party. Financial Times, 10 October.

Feyzioğlu, T. (2009) Does good financial performance mean good financial intermediation in China? IMF Working Papers, 09/170. Washington, DC: International Monetary Fund.

Gabor, D. and Brooks, S. (2016) The digital revolution in financial inclusion: International development in the fintech era. New Political Economy, 22(4): 423-36.

Gonzalez, F. (2015) Where are the consumers? 'Real households' and the financialization of consumption. Cultural Studies, 29(5-6): 781-806.

Goodman, D.S.G. (2014) Middle class China: Dreams and aspirations. Journal of Chinese Political Science, 19(1): 49-67.

Gruin, J. (2013) Asset or liability? The role of the financial system in the political economy of China's rebalancing. Journal of Current Chinese Affairs, 42(4): 73-104.

Gruin, J. (2016). The social order of Chinese capitalism: Socio-economic uncertainty, Communist Party rule and economic development, 1990-2000. Economy and Society, 45(1): 24-50.

Gruin, J. (2019) Communists Constructing Capitalism: State, Market, and the Party In China's Financial Reform. Manchester: Manchester University Press.

Hall, S. (2012). Geographies of money and finance II: Financialization and financial subjects. Progress in Human Geography, 36(3): 403-11.

Hansen, H.K., and Porter, T. (2017) What do big data do in global governance? Global Governance, 23(1): 31-42.

Heath, T.R. (2016). China's New Governing Party Paradigm: Political Renewal and the Pursuit of National Rejuvenation. Surrey: Ashgate. 
Heilmann, S. (2005) Regulatory innovation by Leninist means: Community party supervision in China's financial industry. The China Quarterly, 181 (March): 1-21.

Heilmann, S. (2008) Policy experimentation in China's economic rise. Studies in Comparative International Development, 43(1): 1-26.

Hoffman, S. (2017) Programming China: The Communist Party's Autonomic Approach to Managing State Security. Berlin: Mercator Institute for Chinese Studies.

Hornby, L. (2017) China changes tack on 'social credit' scheme plan. Financial Times, 4 July.

Hsiao, C., Shen, Y. and Bian, W. (2015) Evaluating the effectiveness of China's financial reform: The efficiency of China's domestic banks. China Economic Review, 35: 70-82.

Hsu, S., Li, J. and Xue, Y. (2014). Shadow banking and systemic risk in China. Political Economy Research Institute Working Paper 349. Amherst: Political Economy Research Institute.

Hu, B. and Zheng, L. (2016). China's shadow banking system - Scale, risks and regulation: Research from the perspective of non-traditional credit financing. In: Hu, B., Zheng, L. and Yin, Z. (eds.) Development of China's Financial Supervision and Regulation. Abingdon: Palgrave MacMillan, 129.

Huang, Y., Shen, Y., Wang, J. and Guo, F. (2016) Can the internet revolutionise finance in China? In: Song, L., Garnaut, R., Fang, C., and Johnston, L. (eds.) China's New Sources of Economic Growth: Reform, Resources, and Climate Change. Canberra: ANU Press, 115-38.

Huang, Z., Lei, Y. and Shen, S. (2016) China's personal credit reporting system in the Internet finance era: Challenges and opportunities. China Economic Journal, 9(3): 1-16.

Jia, L, and Winseck, D. (2018) The political economy of Chinese internet companies: Financialization, concentration, and capitalization. International Communication Gazette, 80(1): 30-59.

Karwowski, E., and Stockhammer, E. (2017) Financialisation in emerging economies: A systematic overview and comparison with Anglo-Saxon economies. Economic and Political Studies, 5(1): 6086.

Kshetri, N. (2016) Big data's role in expanding access to financial services in China. International Journal of Information Management, 36(3): 297-308.

Langley, P. (2007) Uncertain subjects of Anglo-American financialization. Cultural Critique, 65(1): 6791.

Li, K. (2014) 2014 Government Work Report [Chinese language]. Beijing: State Council of the PRC.

Li, S.Y. and Tin, C.Y. (2016) Impact of technology on China's financial system. In: Sheng, A. and Soon, N.C. (eds.) Shadow Banking in China: An Opportunity for Financial Reform. Hoboken, NJ: Wiley, 171-94

Lieber, A. (2013). The Chinese ideology: Reconciling the politics with the economics of contemporary reform. Journal of Chinese Political Science, 18(4): 335-53.

Loubere, N. (2017) China's internet finance boom and tyrannies of inclusion. China Perspectives, 2017/4: 9-18. Available at: <http://journals.openedition.org/chinaperspectives/7454>. Accessed 22 November 2019.

Ma, W. (2017) China's Mobile Economy: Opportunities in the Largest and Fastest Information Consumption Boom. Sussex: Wiley.

MacKinnon, R. (2011) China's 'networked authoritarianism'. Journal of Democracy, 22(2): 32-46.

Mader, P. (2016) Card crusaders, cash infidels and the holy grails of digital financial inclusion.

Behemoth: A Journal on Civilisation, 9(2): 50-81.

Martin, R. (2002) Financialization of Daily Life. Philadelphia, PA: Temple University Press.

McNally, C. (2012) Sino-capitalism: China's reemergence and the international political economy. World Politics, 64: 741-76.

Mehrling, P. (2017) Financialization and its discontents. Finance and Society, 3(1): 1-10.

MGI (2017) China's Digital Economy: A Leading Global Force. Shanghai: McKinsey Global Institute. 
Millward, S. (2016) China lacks a US-style credit scoring system. But big data and Al are filling the gap. Tech in Asia, 18 July. Available at: <https://www.techinasia.com/baidu-china-credit-score-systemai-big-data>. Accessed 22 September 2016.

Modell, S. and Yang, C.L. (2018) Financialisation as a strategic action field: An historically informed field study of governance reforms in Chinese state-owned enterprises. Critical Perspectives on Accounting, 54 (July): 41-59.

Muniesa, F., Millo, Y. and Callon, M. (2007) An introduction to market devices. The Sociological Review, 55(2): 1-12.

NDRC (2016) Credit Information Catalogue of the National Credit Information Sharing Plaform (Interdepartmental Joint Membership Conference Unit 2016 Edition [Chinese language]. Beijing: National Development and Reform Commission.

NIFA (2016) Internet finance industry credit information sharing platform launched. Available at: <http://www.nifa.org.cn/nifaen/2955875/2955895/2964303/index.html>. Accessed 17 September 2018.

Ohlberg, M., Ahmed, S. and Lang, B. (2017) Central Planning, Local Experiments: The Complex Implementation of China's Social Credit System. Berlin: Mercator Institute for Chinese Studies.

PBOC (2015a) Report on the Construction and Operation of the Credit System (2004-2014) [Chinese language]. Beijing: People's Bank of China.

PBOC (2015b) Guiding Proposal on Promoting the Healthy Development of Internet Finance [Chinese language]. Beijing: People's Bank of China.

PBOC and NDRC (2017) Notice Concerning Issuing the Name List of the First Group of Social Credit System Construction Model Cities [Chinese language]. Beijing: People's Bank of China and National Development and Reform Commission.

PwC (2015) Banking and Finance in China: The Outlook for 2015. Hong Kong: Price Waterhouse Coopers.

Rethel, L. (2011). Whose legitimacy? Islamic finance and the global financial order. Review of International Political Economy, 18(1): 75-98.

Richards, N.M. and King, J.H. (2013). Three paradoxes of big data. Stanford Law Review Online, 66: 4146.

Shen, W. (2016) Shadow Banking in China: Risk, Regulation and Policy. Cheltenham: Edward Elgar.

State Council of the PRC (2014) Notice of the State Council on the Planning Outline for the Construction of a Social Credit System [Chinese language]. Beijing: State Council of the People's Republic of China.

State Council of the PRC (2015a) Several Proposals of the State Council on Progressing the Healthy Development of Capital Markets [Chinese language]. Beijing: State Council of the People's Republic of China.

State Council of the PRC (2015b) State Council Guiding Opinions Concerning Vigorously Moving Forward the 'Internet Plus' Plan [Chinese language]. Beijing: State Council of the People's Republic of China.

State Council of the PRC (2016) Plan for Advancing Financial Inclusion Development (2016-2020) [Chinese language]. Beijing: State Council of the People's Republic of China.

State Council of the PRC (2017) Notice of the State Council on the 13th Five-Year Plan for Market Supervision [Chinese language]. Beijing: State Council of the People's Republic of China.

STCN (2018) The war on the cloud has started! Regulators lead 16 financial institutions in the construction of a unified financial cloud [Chinese language]. Securities Times, 8 March.

Tang, T., Zhang, Y. and He, D. (2014) The Rise of Digital Finance in China: New Drivers, New Game, New Strategy. Hong Kong: Boston Consulting Group. 
Thornton, P. (2007) Disciplining the State: Virtue, Violence, and State-Making in Modern China. Cambridge, MA: Harvard University Press.

Tsai, K. (2007) Capitalism Without Democracy: The Private Sector in Contemporary China. Ithaca, NY: Cornell University Press.

Tsai, K. (2013) China's political economy and political science. Perspectives on Politics, 11(3): 860-71.

Tsai, K. (2015) The political economy of state capitalism and shadow banking in China. Issues \& Studies, 51(1): 55-97.

Tsai, K. (2017) When shadow banking can be productive: Financing small and medium enterprises in China. Journal of Development Studies, 53(12): 2005-28.

Tsai, W.H. (2016) How 'networked authoritarianism' was operationalized in China: Methods and procedures of public opinion control. Journal of Contemporary China, 25(101): 731-44.

Van der Zwan, N. (2014) Making sense of financialization. Socio-Economic Review, 12(1), 99-129.

Wang, J. (2017) 'Stir-frying' internet finance: Financialization and the institutional role of financial news in China. International Journal of Communication, 11: 22.

Wang, J. (2018) Inclusion or expulsion: Digital technologies and the new power relations in China's 'Internet finance'. Communication and the Public, 3(1): 34-45.

Wang, Y. (2015) The rise of the 'shareholding state': Financialization of economic management in China. Socio-Economic Review, 13(3): 603-25.

Xia, B. and Fuchs, C. (2016) The financialisation of digital capitalism in China. Westminster Advanced Studies, 4: 1-32.

Xiang, X., Zhang, L., Wang, Y. and Huang, C.X. (2017) China's path to fintech development. European Economy, 2: 143-59.

Xie, P., Zou, C.W. and Liu, H. (2014) Internet Finance Handbook [Chinese language]. Beijing: Renmin University of China Press.

Xie, P. (2016a) Internet Finance in China. Abingdon: Routledge.

Xie, P. (2016b) The fundamentals of internet finance and its policy implications in China. China Economic Journal, 9(3): 240-52.

Xinhua (2018a) Social Credit System Construction Demonstration Cities, Introduction of Typical Experience No. 11: Yiwu Municipality [Chinese language]. Xinhua, 6 February. Available at: <http://credit.xinhua08.com/a/20180214/1748625.shtml>. Accessed 16 May 2018.

Xinhua (2018b) China approves personal credit platform for online lending. Xinhua, 22 February. Available at: <http://www.xinhuanet.com/english/2018-02/22/c_136991905.htm>. Accessed 16 May 2018.

Yan, Q. and Li, J.H. (2014) Research on China's Shadow Banking Regulation [Chinese language]. Beijing: Renmin University of China Publishing House.

Yang, D. (2006) Economic transformation and its political discontents in China: Authoritarianism, unequal growth, and the dilemmas of political development. Annual Review of Political Science, 9: 143-64.

Yang, D. (2017) China's troubled quest for order: Leadership, organization and the contradictions of the stability maintenance regime. Journal of Contemporary China, 26(103): 35-53.

Yang, F. (2016) China's National Internet Finance (fintech) Association finally launches credit scoring system. Kapron Asia, 14 September. Available at: <https://www.kapronasia.com/china-bankingresearch-category/china-s-national-internet-finance-fintech-association-finally-launches-creditscoring-system.html>. Accessed September 27, 2016.

Zhang, S. and Ruwitch, J. (2018) Exclusive: Ant Financial shifts focus from finance to tech. Reuters, 5 June. 